\title{
Florida Fishing Guide Requirements Checklist ${ }^{1}$
}

\author{
Elizabeth A. Staugler, Ralph Allen, and Edward V. Camp ${ }^{2}$
}

\section{Introduction}

Florida fishing guides represent an important sector of the fishing industry, providing access to the marine environment and inshore, offshore, and migratory fisheries. The process of running a fishing guide business is complex, with a variety of requirements. This document is designed to assist guides by providing a quick checklist of basic requirements needed to operate as a for-hire guide in the state of Florida and adjacent federal waters. Every fishing guide business is unique, so not all regulations will apply equally. As guides navigate this checklist, they should consider a variety of factors, including the type of charter they run, the vessel they operate, where they operate, and what species they target in order to determine if a requirement applies to their situation.

\section{Basic Requirements}

- U.S. Coast Guard Captain's License (original license must be with you) https://www.dco.uscg.mil/ national_maritime_center/

- Required if guiding from vessel for-hire in coastal waters

- Kayak guides do not need a USCG license.

- Guides fishing freshwaters that are non-navigable to the coast (inland waters not regulated by USCG) do not need a USCG license.

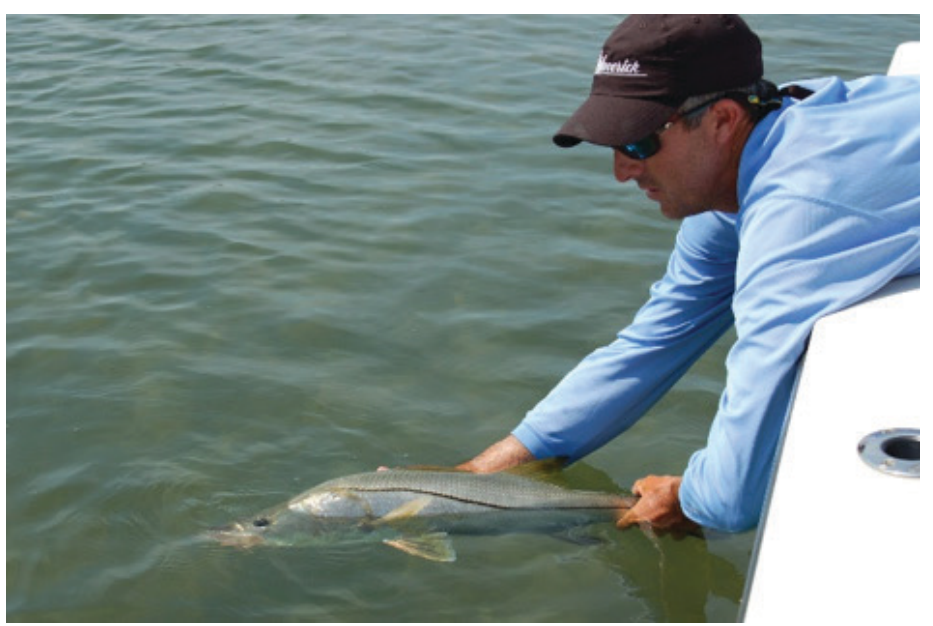

Figure 1. Managing a successful for-hire guide business requires much more than just catching fish.

Credits: Florida Sea Grant

- U.S. Coast Guard Vessel Safety Requirements (in addition to requirements for private vessels)

- Commonly overlooked requirements-not all encompassing. See link for full Uninspected Passenger Vessel requirements: http://wow.uscgaux.info/ Uploads_wowII/P-DEPT/UPV_GUIDEBOOK_under100GT_CGD11_rev052017.pdf

- Type 1 PFDs for all passengers

- Enrolled in an ongoing random drug testing program (must carry proof with you)

- If vessel $>5$ gross tons, must be federally documented with Coastwise endorsement

1. This document is FA218, one of a series of the School of Forest Resources and Conservation, Program in Fisheries and Aquatic Sciences, UF/IFAS Extension. Original publication date April 2020. Visit the EDIS website at https://edis.ifas.ufl.edu for the currently supported version of this publication.

2. Elizabeth A. Staugler, UF/IFAS Extension Charlotte County Florida Sea Grant agent; Capt. Ralph Allen, King Fisher Fleet and Florida Sea Grant Advisory Committee member; and Edward V. Camp, assistant professor, Program in Fisheries and Aquatic Sciences, School of Forest Resources and Conservation; UF/IFAS Extension, Gainesville, Florida 32611.

The Institute of Food and Agricultural Sciences (IFAS) is an Equal Opportunity Institution authorized to provide research, educational information and other services only to individuals and institutions that function with non-discrimination with respect to race, creed, color, religion, age, disability, sex, sexual orientation, marital status,

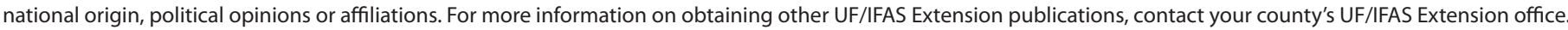
U.S. Department of Agriculture, UF/IFAS Extension Service, University of Florida, IFAS, Florida A \& M University Cooperative Extension Program, and Boards of County Commissioners Cooperating. Nick T. Place, dean for UF/IFAS Extension. 
- If carrying $>6$ passengers, must have Certificate of Inspection issued by USCG

- Florida Charter Captain or Charter Boat Fishing License https://myfwc.com/license/commercial/saltwater/charter/

- State (FL) Gulf Reef Fish Charter (no-charge endorsement on fishing license for Gulf state charters only, excluding Monroe County) https://myfwc.com/license/ commercial/saltwa

- Applies to any state for-hire operation that intends to fish or harvest red snapper, vermillion snapper, gag grouper, red grouper, black grouper, gray triggerfish, greater amberjack, lesser amberjack, banded rudderfish, or almaco jack in Gulf state waters (excluding Monroe County)

- Florida commercial registration for vessel https:// www.flhsmv.gov/motor-vehicles-tags-titles/vessels/ vessel-titling-registrations/commercial-vessels/

- Local city and/or county business license (some call it a $\operatorname{tax})$

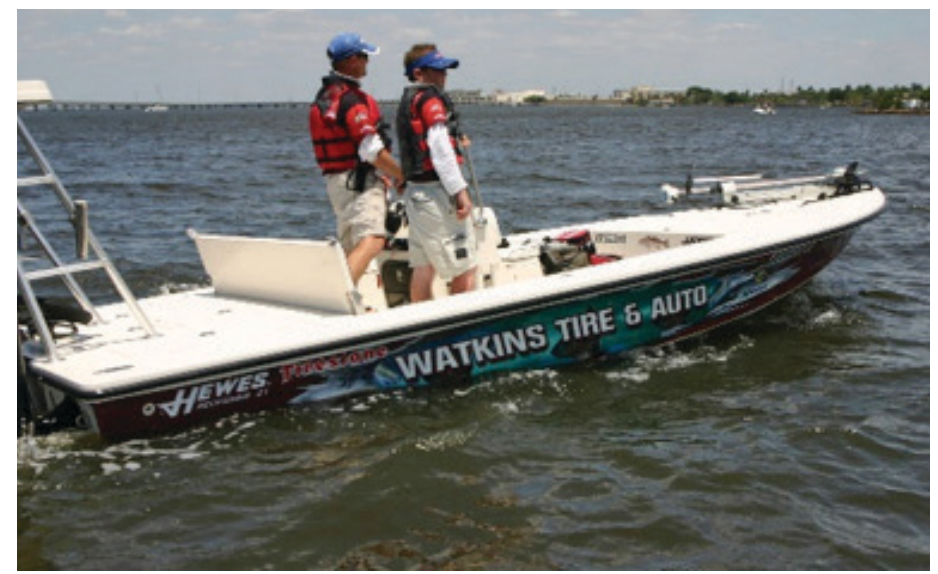

Figure 2. For-hire requirements differ when targeting inshore versus reef species.

Credits: Florida Sea Grant

\section{Federal Waters Permits}

https://sero.nmfs.noaa.gov/operations_management_information_services/constituency_services_branch/permits/ permits_\%20details/index.html

- Atlantic Highly Migratory Species Charter/Headboat Permit (for-hire fishing in federal waters of the Gulf or Atlantic for tunas, sharks, swordfish, and billfish) https:// hmspermits.noaa.gov/

${ }^{*}$ Required in state waters when fishing for bluefin, bigeye, or albacore yellowfin

\section{Gulf of Mexico Federal For-Hire Permits}

- Gulf of Mexico Charter/Headboat Coastal Migratory Pelagics Permit (for-hire fishing Gulf federal waters for king mackerel, Spanish mackerel, and cobia) ${ }^{\star}$ limited access

- Gulf of Mexico Charter/Headboat Reef Fish Permit (for-hire fishing Gulf federal waters for reef fish) ${ }^{*}$ limited access

- Sea turtle release gear is required on all federally permitted for-hire Gulf reef fish vessels (CFR 622.29 [a] [1])

\section{South Atlantic Federal For-Hire Permits}

- South Atlantic Charter/Headboat Coastal Migratory Pelagics Permit (for-hire fishing in Atlantic federal waters king mackerel, Spanish mackerel, and cobia)

- Atlantic Charter/Headboat for Dolphin Wahoo (for-hire fishing in Atlantic federal waters for dolphin or wahoo)

- South Atlantic Grouper/Snapper (for-hire fishing for multiple reef fish species including grouper, snapper, gray triggerfish, sea basses, jacks, porgies, grunts, spadefish, hogfish, and tilefishes)

- Sea turtle release gear is required on all federally permitted for-hire Atlantic Snapper Grouper vessels (CFR 622.179(a)(1))

${ }^{*}$ New reporting requirements for federal permit holders scheduled for summer $2020^{\star}$

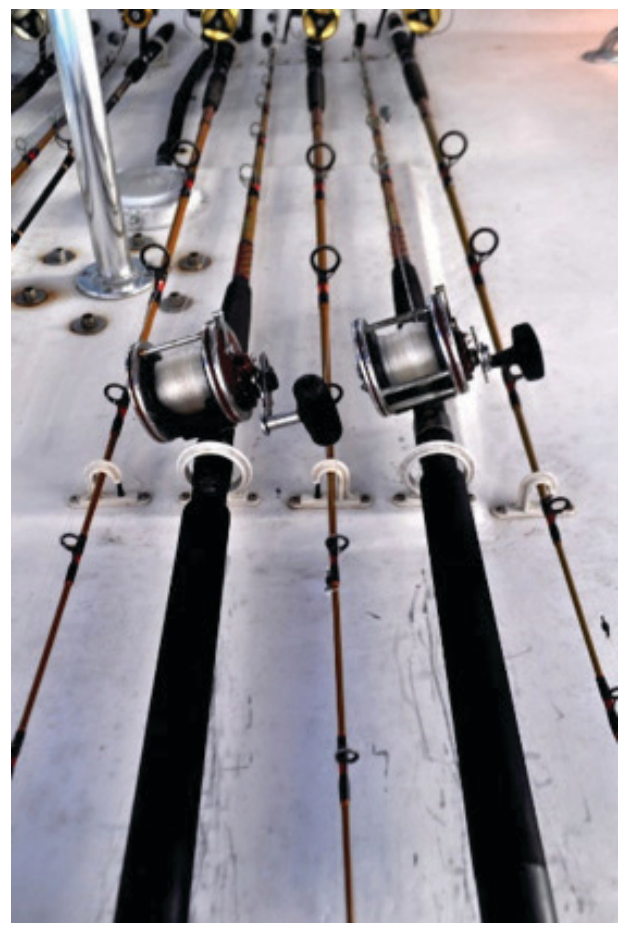

Figure 3. For-hire guides operating in federal waters have additional requirements.

Credits: Jennifer Huber 


\section{State Regulations}

- Florida Charter/For-hire Regulations: https://myfwc. com/license/commercial/saltwater/charter/

- Florida Recreational Fishing Regulations: https://myfwc. com/fishing/saltwater/recreational/

\section{Federal Regulations}

- Gulf of Mexico: https://sero.nmfs.noaa.gov/sustainable_fisheries/gulf_fisheries/index.html

- Atlantic: https://sero.nmfs.noaa.gov/sustainable_fisheries/s_atl/index.html

- Shark regulations for Federal Waters: https://www.fisheries.noaa.gov/atlantic-highly-migratory-species/atlantichighly-migratory-species-fishery-compliance-guides

\section{Conclusion}

Running a fishing guide business means navigating the complicated world of licenses, permits, and safety regulations. This quick guide was prepared to help Florida fishing guides ensure they are compliant with local, state, and federal requirements related to operating a for-hire fishing business. It is important to remember that rules change-like the updates to the Federal For-Hire requirements anticipated in summer 2020. Guides should consult the links from time to time to ensure they are compliant with the most current requirements.

\section{Acknowledgements}

The authors are indebted to the personnel of both state and federal agencies who provided their time and advice in the preparation of this document. 